\title{
An Empirical Study - Adoption of International Financial Reporting Standards (IFRS) in Hong Kong Education
}

Dr WONG Helen

The Hong Kong Polytechnic University

Hong Kong Community College

E-mail: helensmwong@yahoo.com

Mr WONG KH

The Chinese University of Hong Kong

School of Accountancy

E-mail: raykhwong@baf.msmail.cuhk.edu.hk

Received: Sep 9, 2013

doi:10.5296/jmr.v5i4.4256
Accepted: September 30, $2013 \quad$ Published: October 1, 2013

URL: http://dx.doi.org/10.5296/jmr.v5i4.4256

\begin{abstract}
This study aims to investigate students' knowledge and interest on adoption of IFRS in Hong Kong, the preferred strategy and pedagogy of introducing IFRS, and the usefulness of learning IFRS. The results show that most Hong Kong students are eager to learn IFRS and they understand the positive impact of learning IFRS. The Hong Kong accounting professionals and educators have to develop relevant materials on IFRS.
\end{abstract}

Keywords: IFRS, HKFRS, HKICPA 


\section{Introduction}

International Financial Reporting Standards (IFRS) is a global language for business affairs and a set of international accounting standards to assist companies to communicate financial information and to help stakeholders to understand and compare corporate financial information across boundaries. The standards are issued by International Accounting Standards Board (IASB), an independent accounting standard setting body of the IFRS.

Many national accounting standards are replaced by IFRS. More than 100 countries have converged with IFRS for all or some companies or are in the process of doing so. Japan and Canada have adopted IFRS in 2011. China has also released its Chinese Accounting Standards System that brings about substantial convergence with IFRS from 2007 for listed companies. Similar to Europe, Hong Kong has been making use of IFRS for financial reporting since 2005.

It is generally believed that investors and other users of financial statements will be beneficial with the adoption of IFRS (Bau, 2006). The adoption of IFRS among countries can allow comparability of financial information over all financial markets and reduce financial reporting complexity especially for large multinational companies, and investors can also have better information for decision making (Flynn, 2008). However, incompatibility may arise because companies claim to have converted to IFRS but in reality only selected the portions that best fit their needs and smaller companies may not have incentive to follow (Olson, 2008). High cost is also involved in converting from existing localized standards to IFRS (SEC, 2008).

In Hong Kong, the Hong Kong Institute of Certified Public Accountants (HKICPA) adopted the policy of achieving convergence of Hong Kong Financial Reporting Standards (HKFRS) with IFRS in 2001. The objective is to develop a set of high quality, understandable and enforceable financial reporting standards that require high quality, transparent and comparable information in financial statements and other financial reporting to help participants in capital markets and users of the information to make economic decisions. The HKICPA has mandated the Financial Reporting Standards Committee (FRSC) to develop financial reporting standards to achieve convergence with IFRS issued by IASB. HKFRS apply to all general purpose financial statements. Such financial statements are directed towards the common information needs of a wide range of users, for example, shareholders, creditors, employees and the public. The objective of financial statements is to provide information about the financial position, performance and cash flows of an entity that is useful to those users in making economic decisions.

Accounting professional bodies and universities in Hong Kong have gradually integrated IFRS into the accounting programmes and courses. The Qualification Programme (QP) of HKICPA is a comprehensive training programme that provides knowledge and skills necessary to become a Certified Public Accountant (CPA) in Hong Kong. The QP requires candidates to have knowledge in HKFRS which have been gradually converged towards IFRS. A university/college degree student of accredited programmes is eligible to be a QP candidate. The universities or colleges need to plan how to integrate IFRS and HKFRS into 
accounting courses. Knowledge of IFRS makes students understand better the financial information and the implications of any changes in the standards. The objectives of this study are to examine perceptions among business school students about the knowledge of IFRS, their interests in the course and preferred pedagogy.

\section{Literature Review}

IFRS are used in many parts of the world nowadays. Similar to Australia, European Union and South Africa, Hong Kong was mandated to use IFRS since 2005. As of August 2008, more than 113 countries require or permit IFRS reporting. The United States (U.S.) also has a IFRS adoption timeline for trading companies in U.S. The adoption will have impact in education. Universities and colleges have to develop course materials incorporating IFRS for students.

In Canada, Intermediate Accounting courses are affected because they represent substantive coverage of the corporate reporting environment (Conrod J, 2010). In many postsecondary institutions, the role of the Intermediate Accounting course is to develop competency that will provide an appropriate base to support professional accounting study after graduation. The Canadian professional accounting associations have engaged in close co-operation with education partners at the postsecondary level. Active learning assignments are used in course to improve student outcomes (Rebele et al., 1998). Case analysis is also used in classroom sessions (Fry et al., 2003). Resources are available for Intermediate Accounting course on IFRS. Canadian Institute of Chartered Accountants provides supplement materials on IFRS.

Various universities and colleges in the U.S. also integrate IFRS into course work gradually (Nilsen, 2008). At the University of Alabama, the faculty has agreed to work to integrate IFRS throughout the curriculum. At the University of Missouri, students in a graduate accounting policy course are expected to be able to incorporate IFRS into work on various cases. A key challenge for educators is to develop curriculum materials. Adding IFRS on top of U.S.'s Generally Accepted Accounting Principles (GAAP) will affect teaching of other topics. The "bilingual" climate in the U.S. requires careful planning to balance the appropriate proportion of IFRS and U.S. GAAP topics in the CPA exam and academic curriculum. In the U.S., resources on IFRS can be found in websites of the international accounting firms, Financial Accounting Standards Board, American Accounting Association, and Securities and Exchange Commission etc.

In Hong Kong, the HKICPA understands that close co-ordination between the HKICPA's and IASB's due processes is important to the success of achieving convergence of HKFRS with IFRS. It has published in June 2006 Information Paper: Setting HKFRS which outlines the step the Institute plans in supporting the development of IFRS and the implementation of HKFRS in Hong Kong. This Information Paper makes reference to the Statement of Best Practice: Working Relationship between the IASB and other Accounting Standard Setters issued by IASB in February 2006 which identifies a range of activities that the IASB and other accounting standard-setters, including HKICPA, believe should be undertaken by them in the interests of facilitating the ongoing convergence with IFRS. HKFRS were fully converged with IFRS with effect from January 2005. 
The HKICPA has been actively co-operating with IFRS Foundation and IASB. It gave comments and opinions to IFRS Foundation on Due Process Handbook and Trustee's Strategy Review, IASB on Exposure Draft to Proposed Improvements to IFRS in 2012. Although the HKICPA has a policy to achieve convergence of HKFRS with IFRS, the Institute may consider it appropriate to include additional disclosure requirements in a HKFRS or, in some exceptional cases, to deviate from an IFRS. Each HKFRS issued by the HKICPA contains information about the extent of compliance with the equivalent IFRS. HKFRS set out recognition, measurement, presentation and disclosure requirements dealing with transactions and events that are important in general purpose financial statements. They may also set out requirements for transactions and events arise mainly in specific industries. Where the requirements of a HKFRS and an IFRS differ, the HKFRS should be followed by entities reporting within the area of application of the HKFRS.

In the Statement of Best Practice: Working Relationship between the IASB and other Accounting Standard Setters, it mentions on the education aspect that accounting standard-setters should make the International Accounting Standards Committee (IASC) Foundation aware of educational needs in their jurisdictions and provide information about the types of programmes that are likely to be most useful and successful in their jurisdictions, and the IASC Foundation should be sensitive to those needs. The accounting standard-setters should also provide the IASC Foundation with material that they believe may be helpful in creating educational materials. The accounting standard-setters may develop their own educational material as regards to the implementation of IFRS to cater for the local needs and issues.

Universities and colleges in Hong Kong have incorporated IFRS into their accounting courses, such as Financial Accounting, Intermediate Accounting, Advanced Financial Accounting, and Financial Reporting etc. Textbooks incorporating IFRS has been used. The HKICPA plays a key role in converging the IFRS and HKFRS. As the convergence between IFRS and HKFRS is smooth in Hong Kong, the HKFRS reflect the essence of IFRS. The accounting curriculum in schools also tries to match the QP of the HKICPA while HKICPA is responsible for converging HKFRS and IFRS. Therefore the QP candidates in Hong Kong should have knowledge in IFRS.

Hong Kong, being a metropolitan city, it is valuable to investigate:

1 - the need to introduce IFRS in Hong Kong education,

2 - Hong Kong students’ interests in learning IFRS,

3 - Hong Kong students’ knowledge in IFRS ,

4 - the preferred pedagogy of Hong Kong students in learning IFRS,

5 - ways to introduce IFRS, and

6 - the expected outcomes after learning IFRS. 


\section{Research Methodology and Analysis}

This study is based on primary data. The researchers distributed the survey forms to 300 sub-degree (associate degree and higher diploma) and degree business students of Hong Kong. The sample consists of diversified student groups. 136 respondents returned the filled questionnaires. After removing incomplete responses, 114 valid responses were used for data analysis. t-Test and ANOVA are used for analyzing the collected data.

\subsection{Introduction of IFRS in Hong Kong education}

Most of the respondents (97.4\%) agreed that educational institutes in Hong Kong should adopt IFRS in their curriculum. As there is convergence between HKFRS and IFRS, 43\% respondents agreed that they wished to know more about IFRS because it has been adopted in Hong Kong. 20.2\% respondents strongly agreed that having knowledge of IFRS would help them in working in multinational firm and handling global transactions. $41.2 \%$ and $42.1 \%$ agreed that knowing more about IFRS would help them in their jobs and preparing for professional examination respectively. $44.7 \%$ agreed that learning IFRS would help them updating their accounting knowledge which may be important for finding and doing their jobs and studying the professional examination.

\subsection{Interests in learning IFRS among Hong Kong students}

Most of the respondents showed interest in having training on IFRS. With increased familiarity and exposure, $82.5 \%$ respondents were interested to take training on IFRS in near future while $17.5 \%$ showed no interest. $85.1 \%$ respondents would like to choose IFRS as a course in their curriculum.

Knowledge of IFRS will help business professionals to study the information provided in financial reports and to interpret the results. The accounting and finance students are more interested in learning IFRS than other business students. $87.6 \%$ of the accounting and finance students are interested to learn IFRS in near future while $53 \%$ of non-accounting/finance students are interested in it. Among the accounting and finance students, 87.6\% would like to choose IFRS as a course in their curriculum. $70.6 \%$ of non-accounting/finance students would like to choose IFRS as a course.

\subsection{IFRS Knowledge among Hong Kong students}

The adoption of IFRS is an important issue for the business schools in universities or colleges. Academics are developing materials on IFRS. 88.6\% of respondents have heard about IFRS and $53.5 \%$ are aware that HKICPA has adopted IFRS in Hong Kong. Most of the respondents got the IFRS information in schools, $88.6 \%$ got the knowledge during classroom sessions. Hong Kong is a cosmopolitan city with well qualified accounting professionals and educators which would help to enhance the awareness of IFRS among students.

There are no significant differences between male and female students with respect to their awareness on the adoption of IFRS by HKICPA in Hong Kong (p-value $=0.45$ ). There are also no significant differences between accounting/finance and non-accounting/finance students with respect to their knowledge of IFRS (p-value $=0.48$ ). 


\subsection{The preferred pedagogy of Hong Kong students}

To be a modern accounting professional, one should possess technical skills, intellectual skills, personal skills, interpersonal and communication skills, organizational and business management skills (IAESB, 2010). Different ways have been used to encourage development of these skills: active learning assignments (Rebele et al., 1998), case analysis in classroom sessions (Fry et al., 2003), problem-based learning (Hansen, 2006), and simulations and role plays (Fortin and Legault, 2009). Based on the result of this study, more than $80 \%$ students preferred lecture method and $11.4 \%$ students preferred to have case study.

\subsection{The preferred ways of introducing IFRS in Hong Kong}

To have successful adoption of IFRS, it is important to explain the benefits to students, such as preparing for professional examinations, and enhancing career opportunities. More than 85\% respondents replied that their course curriculum has coverage on IFRS at present. 97.4\% agreed that educational institutes should adopt IFRS in their course curriculum. 78.1\% respondents preferred the IFRS to be introduced in their core courses.

There are no significant differences between sub-degree and degree students with respect to their support to the adoption of IFRS in educational institutes' course curriculum (p-value = 0.38). There are also no significant differences between accounting/finance and non-accounting/finance students regarding their views towards the adoption of IFRS in educational institutes’ course curriculum ( $\mathrm{p}$-value $=0.54)$.

\subsection{Expected outcomes of learning IFRS}

More than 50\% respondents agreed and strongly agreed that learning IFRS knowledge and skills would help them in recording business transactions, preparing, reporting and analyzing financial statements. About $40 \%$ respondents agreed and strongly agreed that the learning would help them in making managerial, investing, financial and operating decisions, and running the business. Students, in general, believed that learning IFRS would be useful in their financial reporting functions and decision making.

\section{Findings}

Most of the respondents are aware of the IFRS. There are no significant differences in the knowledge about IFRS for different gender groups and specialization. Second, students are interested to choose IFRS as a course in their curriculum and they prefer it to be a core course of their curriculum. They understand that having knowledge of IFRS would help them in their career development and professional examinations. They are eager to learn IFRS. There is no significant difference between accounting/finance and non-accounting/finance students with respect to the adoption of IFRS in educational institutes' course curriculum. Third, most students prefer to learn IFRS during their lectures. Fourth, most of the respondents agreed that learning IFRS would help them in handling business transactions, reporting financial performance and analyzing financial statements. Finally, the Hong Kong students are ready to learn IFRS. 


\section{Conclusion}

Hong Kong students are eager to learn IFRS. Business schools should incorporate the IFRS in their accounting courses, such as Intermediate Accounting and Financial Reporting. Accounting professionals and education providers should develop materials on IFRS. Professional bodies and education institutions can offer seminars or workshops providing updated accounting knowledge to practitioners, academics and students. There will be a high demand for academic professionals with knowledge of IFRS into the curriculum. Conferences can also be arranged to let professionals and academics exchanging ideas on IFRS.

IFRS are intended to apply worldwide regardless of local legislative and regulatory environments. However, some issues relating to particular legislative and local requirements, such as tax law that is unique to a jurisdiction. To avoid incompatibility with IFRS, accounting standard-settters should liaise with the International Financial Reporting Interpretations Committee in issuing an interpretation.

\section{Limitations and Future Research}

The study was conducted with limited respondents. Future research can be conducted among different sections of the population. The impact of adoption and implementation of IFRS can be surveyed in different business entities.

Table 1. Profile of Respondents

\begin{tabular}{llllll}
\hline $\begin{array}{l}\text { Demographic } \\
\text { Profile }\end{array}$ & Groups & Percentage & $\begin{array}{l}\text { Demographic } \\
\text { Profile }\end{array}$ & Groups & Percentage \\
\hline Gender & Male & 36.0 & School year & Year 1 & 18.4 \\
& Female & 64.0 & & Year 2 & 59.6 \\
& Total & 100 & & Year 3 & 21.1 \\
& & & Year 4 & 0.9 \\
Age & & & Total & 100 \\
& Below 18 & 3.5 & Specialization & Accounting & 79.8 \\
& 18 to 25 & 96.5 & & Finance & 5.3 \\
Above 25 & 0 & & Others & 14.9 \\
& Total & 100 & & Total & 100 \\
& Sub-degree & 39.5 & & & \\
\hline
\end{tabular}


Table 2. Questionnaire Responses

\begin{tabular}{|c|c|c|c|c|c|}
\hline & Questions & & Responses & & \\
\hline 1. & Have you heard about IFRS? & Yes $88.6 \%$ & No $11.4 \%$ & & \\
\hline 2. & Are you interested in learning IFRS? & Yes $82.5 \%$ & No $17.5 \%$ & & \\
\hline 3. & Have you taken any course on IFRS? & Yes $16.7 \%$ & No $83.3 \%$ & & \\
\hline 4. & Should IFRS be adopted in curriculum? & Yes $97.4 \%$ & No $2.6 \%$ & & \\
\hline \multirow[t]{3}{*}{5.} & Are you aware that Hong Kong Institute of Certified & Yes $53.5 \%$ & No $46.5 \%$ & & \\
\hline & Public Accountants has adopted IFRS in Hong & & & & \\
\hline & Kong? & & & & \\
\hline 6. & Does your course curriculum include IFRS? & Yes $86.8 \%$ & No $13.2 \%$ & & \\
\hline 7. & $\begin{array}{l}\text { Would you like to have IFRS as a course in your } \\
\text { study? }\end{array}$ & Yes $85.1 \%$ & No $14.9 \%$ & & \\
\hline \multirow[t]{3}{*}{8.} & Where did you get IFRS information? & Newspaper/ & Classroom & Internet & Others \\
\hline & & Magazine & sessions & & \\
\hline & & $0.88 \%$ & $88.6 \%$ & $1.75 \%$ & $8.77 \%$ \\
\hline \multirow[t]{2}{*}{9.} & How would you prefer in learning IFRS? & Lecture & Seminar & Case study & Others \\
\hline & & $81.6 \%$ & $4.4 \%$ & $11.4 \%$ & $2.6 \%$ \\
\hline \multirow[t]{2}{*}{10.} & Which way should your teachers introduce the & Core course & Elective course & Project work & \\
\hline & IFRS? & $78.1 \%$ & $18.4 \%$ & $3.5 \%$ & \\
\hline
\end{tabular}


Table 3. Questionnaire Responses (in percentage)

\begin{tabular}{|c|c|c|c|c|c|c|c|c|}
\hline \multirow[t]{8}{*}{11.} & $\begin{array}{l}\text { Learning IFRS will help in: } \\
\text { (reasons) }\end{array}$ & $\begin{array}{l}\text { Strongly } \\
\text { Disagree }\end{array}$ & Disagree & $\begin{array}{l}\text { Slightly } \\
\text { Disagree }\end{array}$ & Neutral & $\begin{array}{l}\text { Slightly } \\
\text { Agree }\end{array}$ & Agree & $\begin{array}{l}\text { Strongly } \\
\text { Agree }\end{array}$ \\
\hline & $\begin{array}{l}\text { recording business } \\
\text { transactions }\end{array}$ & 1.7 & 0 & 0.9 & 15.0 & 19.3 & 56.1 & 7.0 \\
\hline & $\begin{array}{l}\text { preparing financial } \\
\text { statements }\end{array}$ & 0.9 & 0 & 0.9 & 12.3 & 21.0 & 54.4 & 10.5 \\
\hline & $\begin{array}{l}\text { reporting financial } \\
\text { position and } \\
\text { performance }\end{array}$ & 0.9 & 0 & 1.8 & 9.7 & 26.3 & 51.7 & 9.6 \\
\hline & $\begin{array}{l}\text { analyzing financial } \\
\text { statements }\end{array}$ & 0.9 & 0.9 & 0.9 & 14.0 & 29.8 & 46.5 & 7.0 \\
\hline & $\begin{array}{l}\text { making operating, } \\
\text { financial and } \\
\text { investing } \\
\text { decisions }\end{array}$ & 0.9 & 0 & 0.9 & 18.4 & 33.3 & 39.5 & 7.0 \\
\hline & $\begin{array}{l}\text { making managerial } \\
\text { decisions }\end{array}$ & 0.9 & 0 & 0 & 19.3 & 38.6 & 35.9 & 5.3 \\
\hline & $\begin{array}{l}\text { running the } \\
\text { business }\end{array}$ & 0.9 & 0 & 1.7 & 27.2 & 30.7 & 35.1 & 4.4 \\
\hline \multirow[t]{6}{*}{12.} & $\begin{array}{l}\text { I want to learn more about } \\
\text { IFRS because: }\end{array}$ & $\begin{array}{l}\text { Strongly } \\
\text { Disagree }\end{array}$ & Disagree & $\begin{array}{l}\text { Slightly } \\
\text { Disagree }\end{array}$ & Neutral & $\begin{array}{l}\text { Slightly } \\
\text { Agree }\end{array}$ & Agree & $\begin{array}{l}\text { Strongly } \\
\text { Agree }\end{array}$ \\
\hline & $\begin{array}{l}\text { it has been adopted } \\
\text { in Hong Kong }\end{array}$ & 0.9 & 0 & 0.9 & 17.5 & 21.9 & 43.0 & 15.8 \\
\hline & $\begin{array}{l}\text { it updates my } \\
\text { accounting } \\
\text { knowledge }\end{array}$ & 0.9 & 0 & 0 & 10.5 & 23.7 & 44.7 & 20.2 \\
\hline & $\begin{array}{l}\text { it helps me to } \\
\text { prepare professional } \\
\text { examination }\end{array}$ & 0.9 & 0 & 0 & 8.8 & 27.2 & 42.1 & 21.0 \\
\hline & $\begin{array}{l}\text { it helps me in my } \\
\text { work }\end{array}$ & 0.9 & 0 & 0.9 & 14.0 & 19.3 & 41.2 & 23.7 \\
\hline & $\begin{array}{l}\text { It helps me to } \\
\text { handle global } \\
\text { transactions }\end{array}$ & 0.9 & 0 & 0 & 10.5 & 27.2 & 41.2 & 20.2 \\
\hline
\end{tabular}




\section{References}

Bau R. (2006). International Financial Reporting Standards (IFRS): pros and cons for investors, Accounting and Business Research.

Conrod J. (2010). IFRS within the Multi-GAAP Canadian Reality: a Teaching and Learning Imperative for Intermediate Financial Accounting, Accounting Perspectives, 9(1), 1-13. http://dx.doi.org/10.1111/j.1911-3838.2010.00001.x

Flynn T. (2008). US warming to IFRS as it moves on from GAAP, http://www.ft.com/cms/s/0/e944709e-7a19-11dd-bb93-000077b07658.html?nclick_check=1

Fortin A., \& Legault M. (2009). Development of Generic Competencies: Impact of a Mixed Teaching Approach on Students' Perceptions. Accounting Education: An International Journal. In Press, Corrected Proof.

Fry H., Ketteridge S., \& Marshall S. (2003). A Handbook for Teaching and Learning in Higher Education: Enhancing Academic Practice. $2^{\text {nd }}$ ed., New York: Routledge.

Hansen J.D. (2006). Using Problem-based Learning in Accounting, Journal of Education for Business, 81(4), 221-224. http://dx.doi.org/10.3200/JOEB.81.4.221-224

International Accounting Education Standards Board (IAESB). (2010). International Education Standard IES 3 Professional Skills and General Education. New York, NY: IFAC

Nilsen K. (2008). On the Verge of an Academic Revolution: How IFRS is affecting Accounting Education. Journal of Accountancy, Dec.

Olson S. (2008). Firms Preparing for New Standards, http://www.cio-today.com/story.xhtml?story_id=11100AYSS1TF\&page=1\&full_skip=1

Rebele J.E., Apostolou B.A., Buckless F., Hassell J.M., Paquette L.R., \& Stout D. E. (1998). Accounting Edcuation Literature Review (1991-1997), Part II: students, educational technology, assessment, and faculty issues, Journal of Accounting Education, 16(2), 179-245. http://dx.doi.org/10.1016/S0748-5751(98)00010-4

SEC Road Map for Transition to IFRS Available. (2008). Journal of Accountancy, Dec. 